\title{
Cryoseismologic Studies for Polar Environment-Recent Progress of Japanese Contribution
}

\author{
Masaki Kanao \\ National Institute of Polar Research (NIPR), Organization of Information and Systems (ROIS), Midori-Cho, Tachikawa-Shi, \\ Tokyo, Japan \\ Email: kanao@nipr.ac.jp
}

How to cite this paper: Kanao, M. (2021) Cryoseismologic Studies for Polar Environment-Recent Progress of Japanese Contribution. International Journal of Geosciences, 12, 6-22.

https://doi.org/10.4236/ijg.2021.121002

Received: December 11, 2020

Accepted: January 15, 2021

Published: January 18, 2021

Copyright (๑) 2021 by author(s) and Scientific Research Publishing Inc. This work is licensed under the Creative Commons Attribution International License (CC BY 4.0).

http://creativecommons.org/licenses/by/4.0/ (c) (i) Open Access

\begin{abstract}
Majority areas of Antarctica and Greenland are under the thick ice sheet and characterized by evolving cryosphere surroundings. In the polar region, associated with the recent trend on climate change such as global warming, glacier relating earthquakes are increasing during this $21^{\text {st }}$ century. In this paper, a decade of progress in "Cryoseismology" at bi-polar regions is reviewed by focusing on the contribution from Japanese researchers. In particular, the specific cryoseismic events are treated, which occurred in the coastal area of East Antarctica, around the Lützow-Holm Bay, together with the coast and whole inland area of Greenland. As the major scientific results, frequency-overtone signals in the harmonic cryoseismic tremors were analyzed by assuming constant sources, suggesting inter-glacial asperities that generate characteristic tremors. Infrasound source locations were also determined by using the array deployment at the coastal regions in the Antarctic. In contrast, characteristics of glacial earthquakes and seismic interferometry approach have been conducted so as to achieve the fine structure of the Greenland Ice Sheet (GrIS) in particular the basal condition beneath the ice sheet.
\end{abstract}

\section{Keywords}

Ice-Quakes, Glacial Earthquakes, Dynamic Cryosphere, Cryoseismology, Climate Change, Polar Regions

\section{Introduction}

The majority of the land of Antarctica and Greenland are buried by thick ice-sheet and also surrounded by evolving cryosphere in their surface environment. In the polar region, associated with recent climate change [1], unique 
earthquake events in relating to cryosphere dynamics are reported in increasing numbers [2] [3] [4]. In these originating cryosphere events, relatively large magnitude events are called "glacial earthquakes", which has majorly been detected at the calving fronts of massive glaciers in Greenland [5]. In contrast, small energy events were so-called "ice-quakes", "ice-shocks", or "cryoseisms" in general naming. "Ice-quakes" are the most commonly used terminology to express these kinds of cryosphere origin seismic events, which include the category of "glacial earthquakes". In this paper, however, there is no strict definition in the usage of these specific terminologies expressing the cryoseismic phenomenon.

Such the cryoseismic sources are defined by several categories in their occurrence dynamics; the ice-sheets, ice-caps, glaciers and ice-streams, icebergs and sea-ices, tide-relating cracks and their calving fronts [3] [6] [7] [8] [9]. Concerning the evidence, these cryoseismic signals can be influenced by environmental conditions surrounding the recording stations, and making a long-term investigation of their variabilities could give rise to useful evidence of global warming. Since large earthquakes involving cryosphere dynamics are the most remarkable around Greenland [2] [5] [10], these kinds of seismological monitoring for cryosphere evolution are especially stimulated by making continuous observations under a strict meteorological environment in high latitudes.

Considerable origins of the occurrence of cryoseismic events have been known as multi-genetics. For example, "ice-quakes" recorded in the Antarctic region could be excited by the energy of several phenomena in surface layers of the Earth, coupled with the ocean-atmosphere-cryosphere-solid earth system ([11], Figure 1). In these characteristics having multi-generic aspects, seismological research for cryosphere (including those who are making studies on wave propagation characteristics, reconstruction of source mechanism, in addition to seismicity) are so-called "Cryoseismology"; which has been known as a new branch of geosciences by inter-disciplinary approaches collaborating with other geoscience branches of geophysics, geodesy, and glaciology.

In the paper, recent progress in "Cryoseismology" by focusing on Japanese contribution is reviewed by focusing on the major scientific achievements in seismic and infrasound investigations. The new findings and technology involving the studies on "glacial earthquakes" could give rise to new insights into an understanding of ongoing dynamics of the cryosphere, as well as underlying crystalized Earth's crust and upper mantle.

\section{Arctic Region}

\subsection{Glacial Earthquakes in Greenland}

A recent trend on cryosphere evolution in the Arctic represents a rapid decrease of the ice-mass based on satellite images, especially around the Greenland Ice Sheet (GrIS) and adjacent glaciers [13] [14]. In parallel with retreat process of the mass of the GrIS, "glacial earthquakes" associated with dynamics of calving fronts of ice-streams, as well as the edges of the GrIS are remarkably reported during a last decade [2] [5] [15] (Figure 2). Understanding of the seismic source 


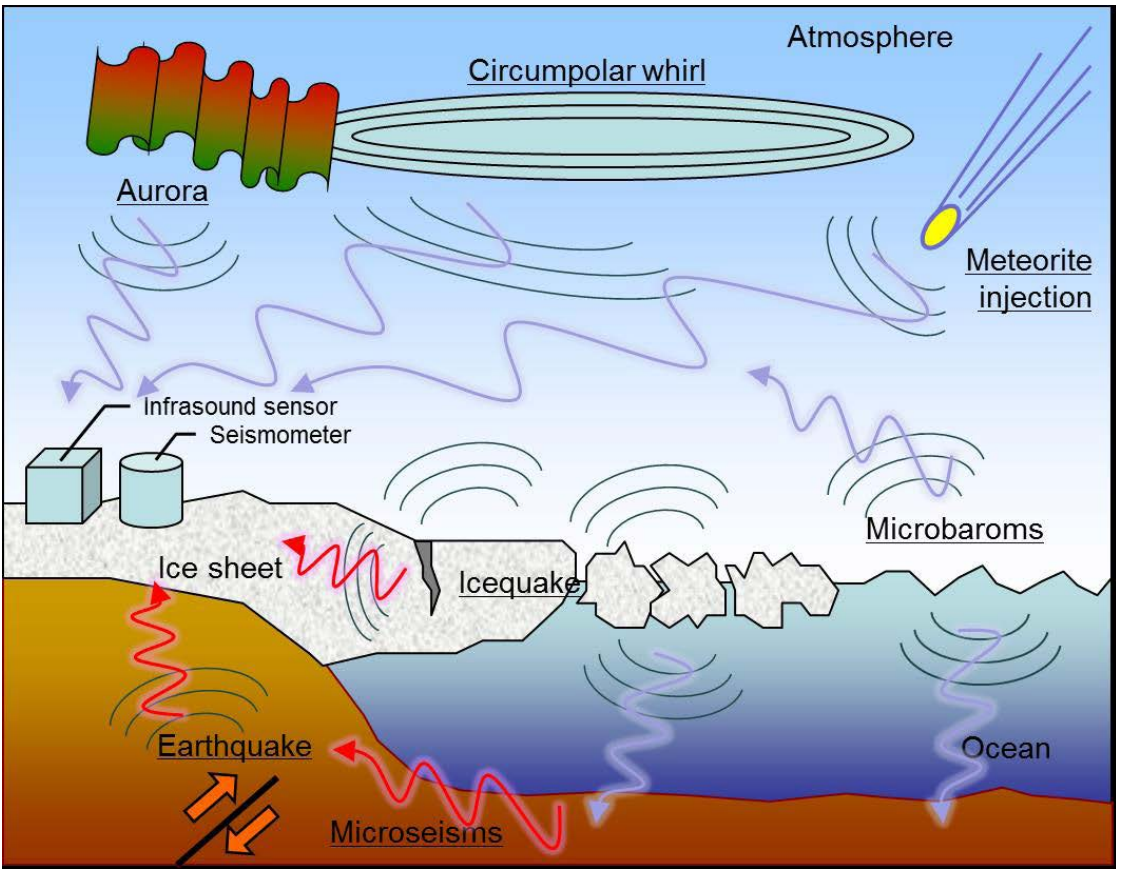

Figure 1. Schematic illustration of excitation in the atmospheric pressure and seismic waves in the polar regions. Physical interaction between solid earth, atmosphere, ocean and cryosphere will be detected by using infrasonic waves, which have been generated by several sources around the coast of continents and surrounding oceans (modified after [12]). Copyright Clearance Center (CCC, http://www.copyright.com/); License Number: 4605231118395, License date: June 10, 2019 (one of the authors is M. Kanao).
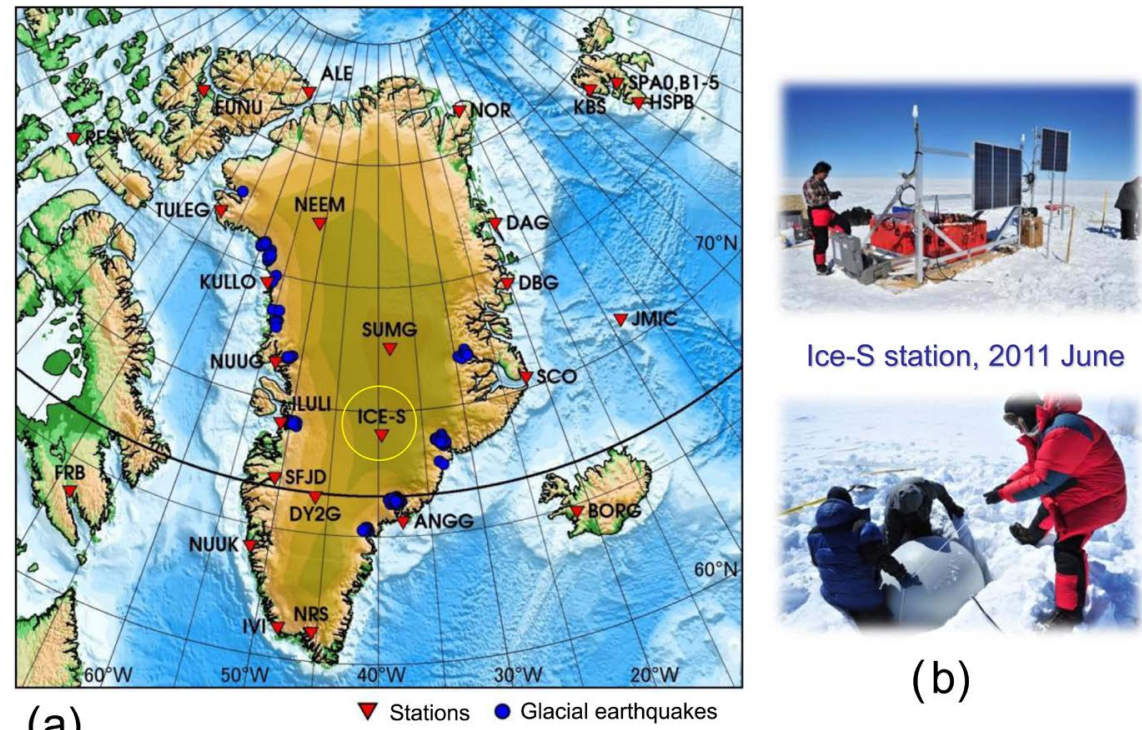

Ice-S station, 2011 June

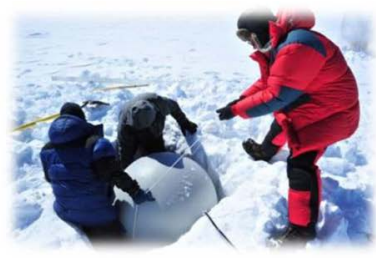

(b)

(a)

Figure 2. (a) Hypocentral distribution of glacial earthquakes around Greenland and the vicinity in 1993-2008 (indicated by blue circles). Seismic stations including both permanent and temporal ones are indicated by red triangles. Hypocenters of glacial earthquakes are referred from [10] (figure is modified after [16]). (b) Photos of installation of ICE-S station over the Greenland ice sheet on June 2011. Location of the station is represented by open yellow circle on the map of Greenland. Open Access Journal (CC BY 3.0) (first author is M. Kanao). 
parameters and time-space distribution of hypocenters of cryoseismic events in Greenland should give rise to a sufficient knowledge for understanding the amplification process of the melting GrIS in relating to global warming in the Arctic.

A glacial earthquake has been generated in terms of cryosphere dynamics, in spite of their source mechanism were unclear so far in bi-polar regions. Moreover, geodesic researchers in the polar areas have been revealed the relationship between the occurrence of cryoseismic events and the Glacial Isostatic Adjustment (GIA). The GIA is involved in sea-level rise caused to some extent by deglaciation from the past glacial maximum over ten thousand years ago. Therefore, a study on the currently occurring cryospheric seismic events might be a new proxy for watching environmental variations in the bi-polar regions associated with the interaction between multi-sphere (i.e., the cryosphere, atmosphere, ocean, and solid Earth) [16].

To investigate the GrIS dynamics by seismological approach, an international research initiative named the "GreenLand Ice Sheet monitoring Network; GLISN" had been launched at the International Polar Year (IPY2007-2008) by fourteen countries involving the Arctic research and global seismological community, led by the USA, Denmark and Japan [10] [17]. The project was initially funded by the National Science Foundation (NFS), and the USA was the leading partner. Combined analysis with the data from existing global networks (the Federation of Digital Seismographic Network; FDSN), generation mechanism of glacial earthquakes would be investigated shortly associated with GrIS mass shrinking process. Moreover, cryosphere evolution and sea-level rise might be investigated by connecting the amplification process of global warming in the Arctic.

Comparing the seismicity of cryoseismic events in bi-polar regions, moreover, could be conducted by making use of a statistical approach by the ETAS (Epidemic Type Aftershock Sequence) model [18]. Statistics in seismicity for both the ordinary crustal events and glacial related events was already investigated in terms of plate tectonics, distribution of volcanos around Greenland and northern Atlantic Ocean [11]. Active region for glacial event seismicity was migrated from southeast to northwest area in Greenland during the last one decade [19]. This tendency of few years in seismicity corresponds to the variations of GrIS mass loss, which are detected by the image from Gravity Recovery And Climate Experiment (GRACE) satellite [14].

\subsection{Seismic Interferometry}

A study on the basal conditions of GrIS is a vital scientific target regarding climate variation because the bottom state of the GrIS cannot be investigated by other methods such as surface glaciological sampling and satellite images. The meltwater was considered to affecting the occurrence of stick-slip type cryoseismic events around the deeper part of GrIS [20] by seismic array deployed at the western part of Greenland. A new inter-disciplinary geophysical network of 
GLISN has also given rise to a unique infrastructure composed of a continuous recording of the surface condition of the GrIS. The seismic interferometry approach was recently conducted by using waveform data retrieved from GLISN [21].

The GLISN project deployed thirteen broadband seismic stations at Greenland [10] [17]. Daily obtained cross-correlation functions; CCFs for the capable pairs of the GLISN seismic-stations were calculated [21]. Resultantly, almost constant group velocity for Rayleigh waves was obtained as $2.8 \mathrm{~km} / \mathrm{s}$ for the period in 2 - $14 \mathrm{~s}$ by the pair of NEEM-SUMG, where is over the ridge of Greenland ice-cap (Figure 3 ). The main source of the ambient-noise has been known as the "microseism", which was generated at the offshore in the southern part of Greenland.
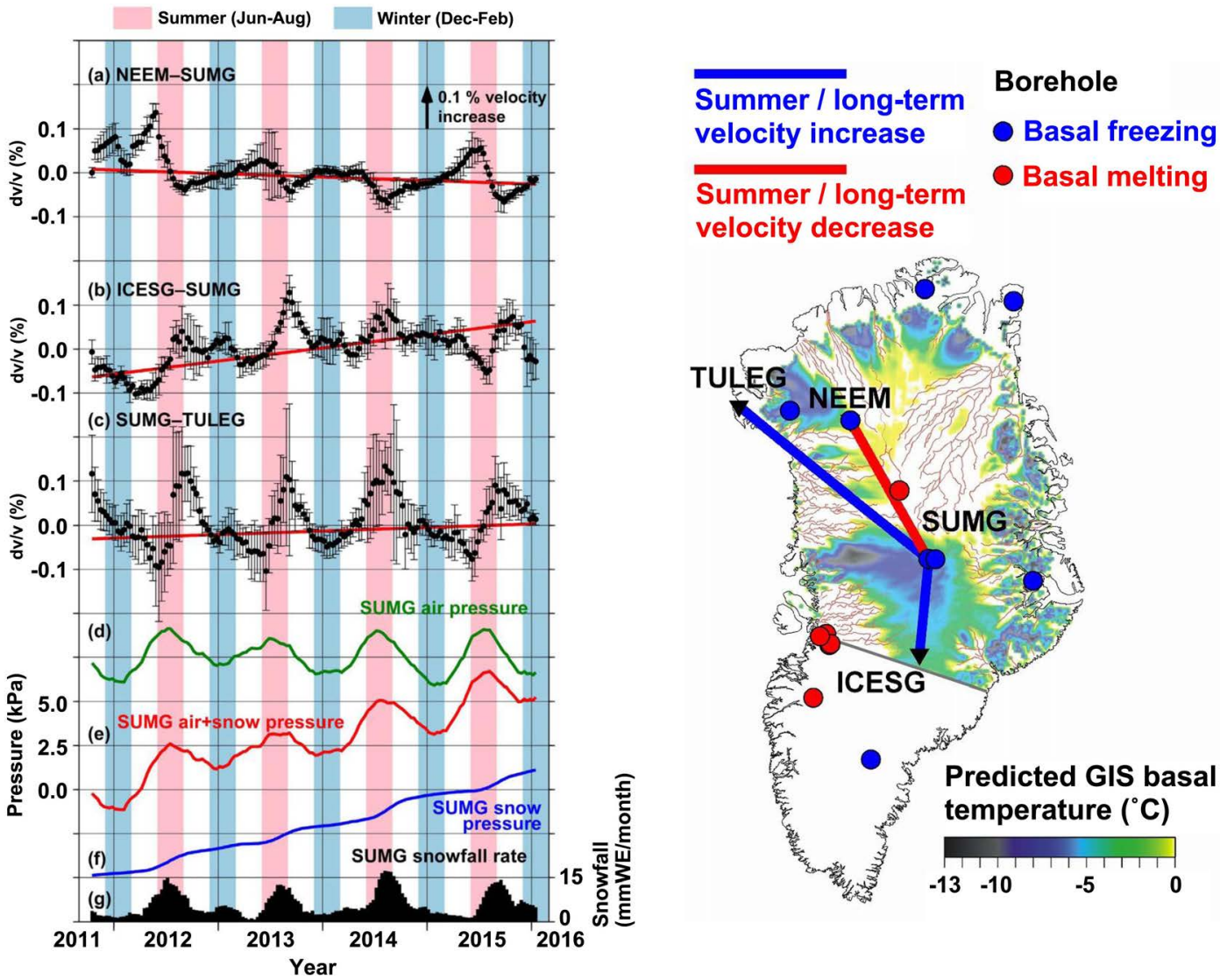

Figure 3. (left) Seismic surface wave (Rayleigh-wave) phase velocity variations at three station pairs over 4.5 years in Greenland. Comparisons of changes in Rayleigh-wave phase velocity with air pressure and snowfall for 4.5-year period. Profiles of velocity changes for (a) NEEM-SUMG, (b) ICESG-SUMG, and (c) SUMG-TULEG pairs. Measurements of relative velocity changes for the three-month time windows $(d v i l v)$ are shown by black dots with two-standard-error bars $(2 e d v i l v)$. Slopes of regression lines (red lines) indicate long-term velocity changes. Pink and pale blue bars indicate summer (Jun-Aug) and winter (Dec-Feb) months, respectively. Three months' average of (d) air pressure from data assimilation [22], (e) a joint air and snow pressure, (f) snow pressure, and (g) observed water equivalent (WE) snowfall [23] at station SUMG, are also displayed. Note that $(\mathrm{f})$ is obtained by integrating double amplitude of $(\mathrm{g})$, and $(\mathrm{e})$ is obtained by $(\mathrm{d})+(\mathrm{f})$. (right) Comparison with estimated basal temperature beneath the Greenland Ice Sheet (GrIS) [24]. (modified after [21]). Open Access Journal (CC BY 3.0) (one of the authors is M. Kanao). 
Ambient noise data were used from all GLISN stations over Greenland for a period of 4.5 years. Rayleigh wave phase velocity for all capable station pairs was determined to detect their timeline variations [21]. They found both the seasonal and a few years of length variations in the Rayleigh wave phase velocity for a significant number of the pair of stations, followed by proposing a plausible mechanism to explain the differences. Essential factors to generate velocity timeline variations might be seasonal and a few years of length ice mass changes such as the load/unload of the ice-sheet and underlying sediment layers over the bedrock topography. However, local heterogeneity of basal conditions of the GrIS might affect substantial regional variability on the identified tendency.

As a striking feature, though the nearby two-station pairs over the ice-sheet plateau of Greenland, a pair represented velocity decrease (i.e., NEEM-SUMG in Figure 3 ) in contrast the other indicated increase (i.e., TULEG-SUMG and ICESGSUMG in Figure 3) according to as the resultant from condensed snow-ice-air pressure characteristics. A former couple of the pair was located at the thawed bedrock area and was assumed to be decreasing velocity in terms of increasing meltwater caused by pressure melting. In contrast, the latter pair could be identified where the frozen bedrock areas have increasing velocity caused by the compaction procedure of the ice-sheet together with underneath the sediment layer above the bedrock. These obtained results suggested that information from surface wave analyses was susceptible to the basal conditions of Greenland ice-sheet. Continuous monitoring of the surface and inner structure of the GrIS might give rise to the quantitative achievement of the ice mass balance estimation in the surface environment on the ice-sheet.

\subsection{Perspectives in the Arctic Cryoseismic Studies}

By using waveform data obtained from GLISN stations, seismic source mechanisms to generate cryoseismic events will be demonstrated on the assumption of the landslide-type source mechanism for calving-type glacial earthquakes. Accurate source mechanism information (fault parameters, radiated energy, etc.) might suggest a precise occurrence location inside the ice-sheet. In addition, by a comparison of observed and synthetic seismograms, the validity of the assumed seismic-source types might be evaluated using inversion methods.

Besides the dynamic processes of calving events and basal melting for individual glaciers in relating to glacial earthquakes, another seismic activity occurs associated with the uplift of crystalline solid Earth (GIA relating events) involving regional/local deglaciation (for example, the Hudson Bay area, the Baltic Bay area in the northern hemisphere). The areas were in the middle part of several continental brocks existing in the northern hemisphere and had been covered by thick ice-sheet in the past more than ten-thousand years ago [25] [26]. Regarding the Laurentide ice-sheet, for instance, time-space variations in the tectonic stress field regime within the crustal depths, as well as the occurrence characteristics of small/microearthquakes was clearly demonstrated [26]. 


\section{Antarctic Region}

\subsection{Cryoseismic Studies before and at the IPY}

There are a number of candidates for originating cryoseismic sources in the Antarctic region, for instance, around Syowa Station (69.0S, 39.6E, SYO), inside East Ongul Island at the northern part of the Lützow-Holm Bay (LHB), in the Eastern Droning Maud Land of East Antarctica. Cryoseismic events were observed associated with dynamics of sea-ices, icebergs, ice-cliffs, calving of glaciers and ice-streams, solid earth response against oceanic swells (microseisms), vertical movement of sea-ice in terms of oceanic tides, opening tide cracks, discharges of fast-ice from LHB, and the other cryosphere origins [11].

As the most frequently observed events by cryoseismic origins, tide-crack generating events with small magnitudes at the coasts of East Ongul Islands could generate a significant number of ice-shocks with small energy release. Overlying sea-ices above marine water vary their elevation within a few meters, corresponding to the level change of oceanic tides. When the sea level decreased, most of the tide-cracks opened and radiated seismic energy. A tight relationship between daily variations of oceanic tides and timeline characteristics of the occurrence frequency was reported at the events occurring around East Ongul Island [27]. Over ten-thousand ice-shock events were detectable at SYO during a whole season; however, a large number occur from austral spring to summer, and autumn when the temperature rises to increase the number of cryodynamic events.

Another striking example of cryoseismic events in LHB was the discharge of fast sea-ice in the 1997 winter season [11]. Harmonic-overtone seismic tremors with a few $\mathrm{Hz}$ frequency contents were recorded by a three-component broadband seismograph at SYO with duration times over a few hours. The harmonic-overtone seismic tremors were presumably occurred associated with friction dynamics between fragments of icebergs, fast- and pack- sea-ices in and around the LHB. Another candidate for tremor source was the collision between the digging icebergs and the oceanic bottom was inside the continental shelf of the Bay.

When looking at other areas in Antarctica, for instance, evaluation of timespace variation for cryoseismic events give rise to information on cryosphere dynamics in central Dronning Maud Land. A pattern of cryoseismic events was classified in the region around Ekstrom Ice Shelf, East Antarctica [9]. Seismic array at the Neumayer Station recognized characteristic events around the coast of the ice shelf. Their detected signals can be explained by the initiation of fractures and involved resonance inside water-rich cavities. A number of these events have a tight relationship with the dominant tidal periods. A cracking system might be developed according to an increase in the stresses inside existing glaciers through their bending movement. By considering this model, the cryoseismic signals were generated when the stage of raising the level of oceanic tides. The cavities might have been expanded at the glacier basement, where the boundary between oceanic water injection and the bottom of the cryosphere. 
In terms of long-term variations in teleseismic detectability, a response to cryosphere evolution surrounding the station was investigated around SYO [28] [29]. Time-space features of the source parameters for these detected events, such as magnitude dependency, spatial-depth distributions, both long-term and seasonal trends were studies using a statistical approach. Overlapping on the increase of the detection number for teleseismic earthquakes, technological development for recording/acquisition hardware/software including a dynamic range of seismographs, as well as the improvement of seismic phases read-out techniques, might increase the detectability of teleseismic events at SYO. When eliminating the effects of technical development and artificial effects, long-term detectability could be involved in cryospheric evolution, meteorological conditions, in particular extended area and thickness of sea-ices surround the LHB.

\subsection{Seismic Tremors with Harmonic Overtones}

Characteristic tremors with harmonic overtones have been recorded in LHB in 2014-2015 [30] [31]. Short- and long-period seismographs recognized more than 120 tremors at SYO during the period. Most of the tremors represented features of clear harmonic overtones, with the frequency content over $1 \mathrm{~Hz}$ and duration times for a few tens of minutes. These overtones might be implied by natural repetitive sources [6] [32], that is, a kind of strong inter-glacial asperities among cryosphere environment surroundings. However, these kinds of harmonic tremors could be generated by a sort of collision mechanism, suggesting a collision between icebergs and sea-ices from LHB, otherwise those between icebergs and oceanic bottom (oceanic floor) of the Bay. Similar features of harmonic tremors involving drifting icebergs have been identified by hydro-acoustic waves in both the Southern Indian Ocean and Pacific Oceans [33].

Detailed measurement and classification of ice-related tremors were also conducted by using the data of SYO [34], on the basis of their waveform features and timeline variation of the detected number. The "ice tremors" were seismic events with non-clear arrivals for $\mathrm{P}$ and $\mathrm{S}$ waves within 5 minutes of the duration-times. A total of 430 ice-tremors were identified during 2013-2015. The monthly number of tremors correlates well with the temperature of each month except for January-March. Tremors were classified into three types; A) Long duration ones (over ten thousand of seconds) having small amplitudes; B) Dominant frequency variations non-linear trends over the wavelets; C) Dominant frequency gradually decreasing with overtone characteristics. In April 2006, a sizeable tablet-type iceberg generated tremors with a similar feature in type $\mathrm{C}$, which was also reported at Neumayer Station in the central Dronning Maud Land [35].

These characteristics are supposed to be associated with cryospheric origin in the vicinity of the observation area. As a theoretical approach, in contrast, [36] modeled harmonic tremors along Whillans Ice Stream of West Antarctica. The tremors were explained by episodic swarms composed of small-scale repeating events. These tremors were uniformly occurred in series like manner, with their 
space interval of spectral peaks on $10-20 \mathrm{~Hz}$. A numerical model of these tremors' appearance features gave practical information on the mechanism for rate/state-dependent friction. After a comparison between synthetic and observed seismographs, the fault patches were estimated to be $10 \mathrm{~m}^{2}$, bed shear modulus of $20 \mathrm{MPa}$, adequate pressure of $10 \mathrm{kPa}$. These series of slip events were identified to happen twice a day, regardless of the skipped phenomenon were increased in frequency over the past few years. The probable source origins of harmonic tremors in LHB have still been unclear. However, the theoretical approach, as mentioned above, could give useful information on estimating the origin of these tremors.

\subsection{Source Location Identification}

Figure 4 shows the source location estimation for two ice-tremor events (type C) on 1 April (left) and 5 April (right), 2015, respectively (modified after [34]).

\section{(a) $2015 / 04 / 01$}

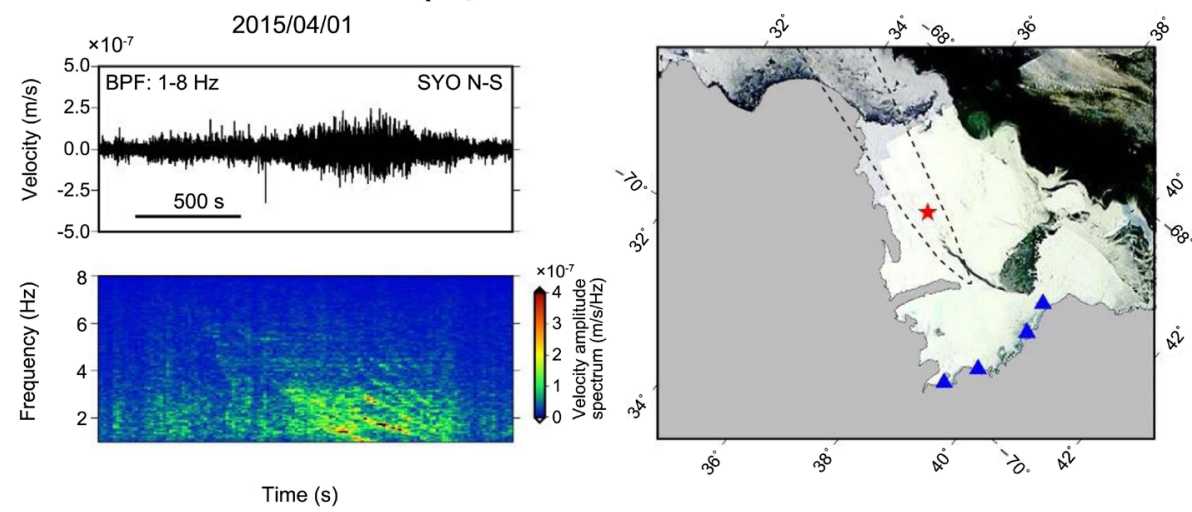

\section{(b) $2015 / 04 / 05$}
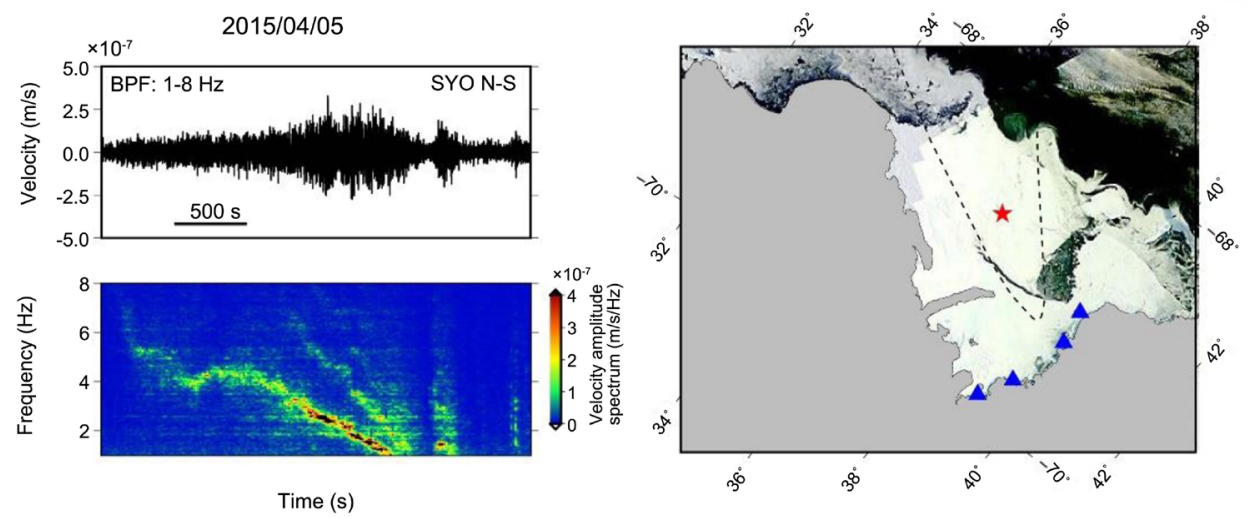

Figure 4. Source locating of two ice-tremor events (type C; harmonic tremors) (modified after [34]). (upper; a) On 1 April 2015 and (lower; b) on 5 April 2015. (left) Examples of seismic waveform and spectrogram at Syowa Station (SYO). (right) A red star corresponds the source location of the detected event. The area enclosed by a dashed line is the $95 \%$ confidence area of the source location and blue triangles are the seismic stations in the Lützow-Holm Bay (LHB) used for source locating. Background image is the MODIS imagery on 11 April 2015. Copyright Clearance Center (CCC, http://www.copyright.com/); License Number: 4605240478514, License date: June 10, 2019 (one of the authors is M. Kanao). 
Upper-left panels for each figure correspond to the waveforms and spectrograms at SYO. Upper-right panels indicate red stars for which represent source locations of the detected events. The areas enclosed by dashed lines are the $95 \%$ confidence areas for estimation of the occurring locations; the blue triangles represent seismic stations utilized for the determination of locating seismic source points. Both the source locations in early April 2015 events were determined inside LHB, where a significant volume of sea-ice was discharged caused by the collision of drifted large icebergs together with the effects on injection of warm water produced by coastal ocean current toward the LHB. The harmonic tremor events assumed to be caused by several collisions between fragments of sea-ices and icebergs, which had been drifted from east to west along the continental shelf.

The infrasound (atmosphere pressure waves which having sub-audible frequency bands) arrays deploying at LHB cleared temporal changes in frequency context and propagation back azimuth from the source events [12]. Time-space variations of infrasound source positions from January to August 2015 were studied by using two arrays deploying in LHB [37]. The pair of arrays obtained temporal variations for propagation direction during eight months in 2015 (Figure 5). A few hundreds of excitation positions were located, and most of the sources were located to be in the northward orientations from the arrays. Moreover, majority of the sources had frequency contents of a few Hz. Since the "microbaroms" from the ocean have 0.2 dominant frequency contents in LHB, most of these events are supposed to be cryosphere origin around LHB. By making a comparison with MODIS satellite images, the excitation sources of infrasound were considered to be involved in several features depending on the location of the sources. For example, relatively low-frequency contents of a few $\mathrm{Hz}$ from the Bay orientation represent the events associated with the discharge of sea-ice, laming signals between the fragmentation of sea-ices and collisions with icebergs. In contrast, the events with relatively high-frequency contents of $5-10 \mathrm{~Hz}$ came from the coastal area of the continental ice sheet, that is, from the area existing glaciers and ice-streams.

Compared with the estimated source locations of infrasound excitation by using two arrays in LHB on 19 April, 2015 overlapping on the MODIS image (Figure 5), the two ice-tremor events (type C; Figure 4; [34]) have different characteristics in their wavelet features. For instance, seismic tremors with harmonic overtones have relatively large energy which can be determined as seismic sources. On the contrary, the infrasound sources have relatively small energy with predominant frequency contents of few $\mathrm{Hz}$. Source locations determined by both the seismic arrays and infrasound arrays are also identified as the different positions to each other. That is, at the northern edges of fast-sea-ices in LHB for seismic harmonic tremors, in contrast, an open-sea area with the mixture by fragmentation of sea-ices, icebergs in the middle of LHB for infrasound source locations, respectively. These evidence of different hypocentral locations indicate the source mechanism of both kinds are different regime, the former (seismic 


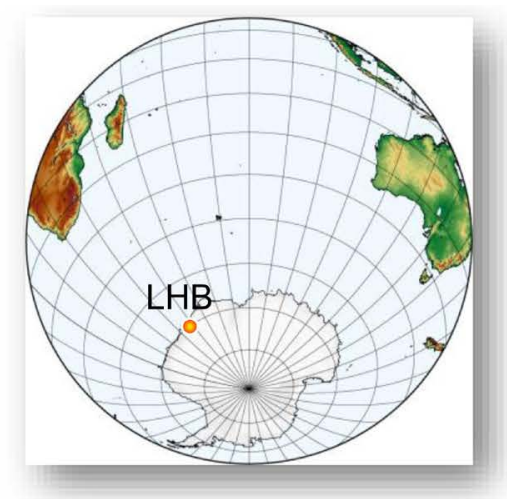

MODIS satellite image around LHB, 20150419

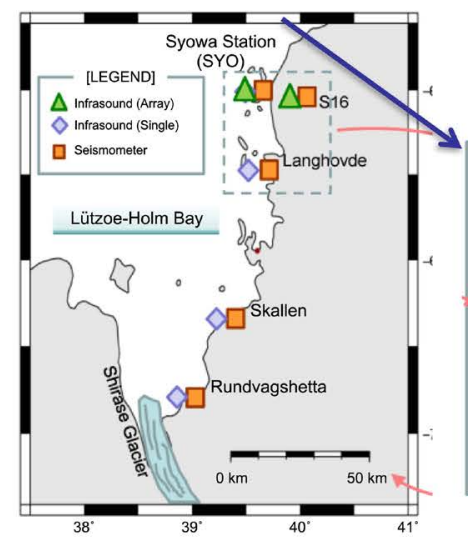

(a)

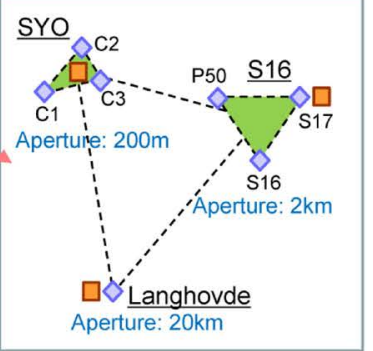

(b)
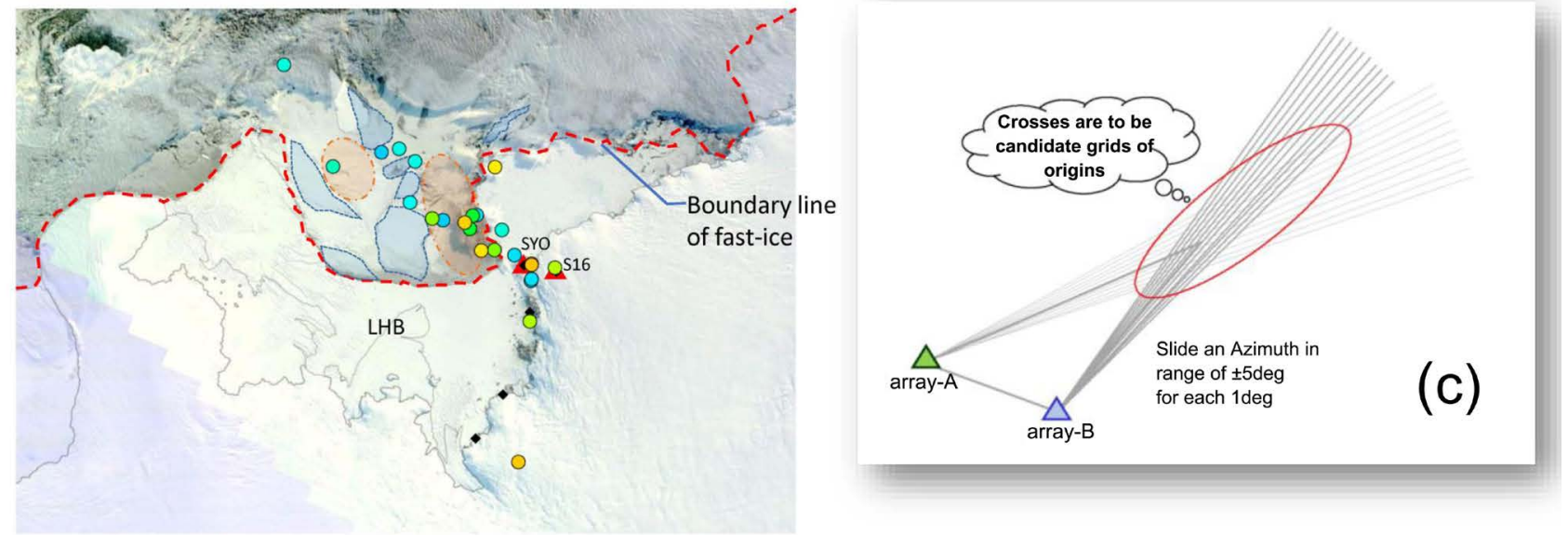

Figure 5. Time-space variations of infrasound sources involving environmental dynamics around the Lützow-Holm Bay (LHB) (modified after [37]). (upper right; a-left) Locations of array deployment in LHB. Array stations of infrasound (green triangles), single stations of infrasound (blue diamond) and broadband seismometers (orange squares) are shown respectively. (upper right; a-right) Array configuration of infrasound stations in order to localize the source signals. Tripartite arrays have been deployed by small size (at Syowa Station (SYO); aperture of $200 \mathrm{~m}$; C1, C2, C3), medium size (at S16, S17, P50; aperture of $2 \mathrm{~km}$ ) and large sizes (combination of other outcrop stations such as Langhovde, aperture of $20 \mathrm{~km}$ ). (lower left; b) MODIS satellite image around LHB on April 19, 2015. Massive volume of fast-ice had discharged from LHB associated with collision by icebergs. The light blue colored areas correspond to the location of the icebergs in previous day. Orange colored areas indicate the pack-ice regions where dynamic movements were considered to be generated during the last one day. Addition, estimated source locations of infrasound excitation are also overlapped on with MODIS image by using two arrays of the SYO and S16. (lower right; c) Flow chart of methodology for estimating source origins by two infrasound arrays (using the progressive multi-channel correlation (PMCC) algorithm). Copyright Clearance Center (CCC, http://www.copyright.com/); License Number: 4605241101749, License date: June 10, 2019; (one of the authors is M. Kanao).

harmonic tremors) are assumed to be active collision schemes such as by the fast-sea-ices and icebergs, otherwise with seafloor of the Bay. The latter (infrasound sources) are characterized by the collision with relatively less energy and a short duration of few minutes at the surface of the sea ice area, which is mixed by fragmentation of sea-ices, icebergs which are drifting over oceanic swells in the Bay.

The most plausible candidate of the source origins for the ice-tremors with harmonic overtones detected by seismic arrays in LHB could be collision events between the bottom of drifting large icebergs with the surface of sea-bedding se- 
diments/crystalline rocks at the northern edges of the continental shelf of LHB. Two determined hypocenters of the ice-tremors [34] locate the areas where the depths of the oceanic floor (bathymetry) approximately $600 \mathrm{~m}$ from the mean sea level [38]. However, there have not been compiled the sufficient volume of bathymetry data in and around LHB so far in order to make detail discussion for revealing iceberg collisional dynamics as well as precise imaging of the tracking pass of the root of icebergs over the oceanic floor. In this regard, further investigations for detecting the detailed topography of the marine floor at the northern edge of the continental shelf could be strongly expected by using the adequate mapping tools such as multi-narrow beam system equipped in the icebreaker vessel "Shirase".

\subsection{Local Array Deployments}

The cryosphere environment around LHB has continuously developing surface cracking system and recorded by seismographs in particular during summer seasons in the Antarctic. Seismic array deployments inside East Ongul Island were recently conducted so as to identify cryoseismic signals in the vicinity of the station [39] [40]. To define the source locations of cryoseismic events around SYO, they conducted seismic array observation during a few months in 2015. They installed seven temporary stations on outcrop sites where locating $1 \mathrm{~km}$ southward from the central station of SYO. The arrays consisted of $1 \mathrm{~Hz}$ geophones of three-component in $100 \mathrm{~m}$ array spacing.

In the observation, two local events were clearly identified. One incident occurred between 11 January and 12 January, which was estimated as the breaking (laming) signals of sea-ice conducted by Japanese icebreaker vessels when approaching East Ongul Island. Peak frequencies of these events were approximately $10 \mathrm{~Hz}$. The following events were found on 14 January with their duration-time of 30 minutes and the peak frequencies of 2, 4, and $6 \mathrm{~Hz}$. The second event propagated from south-southeast with small slowness, indicating the origin of the source might be local ones, i.e., the tidal modulated dynamics surrounding the East Ongul Island.

In the future study, similar waveform events like local seismic tremors will be defined by conducting continuous monitoring of seismic observations at SYO and the vicinity area. In addition to the permanent station monitoring, temporal array observations by using multiple seismometers conducted like [39] [40] could be useful tools to determine the accurate hypocenters and source mechanism of the Tremor-Like Signals (TLS) [41] and associated emission events, which have also been observed at the SYO seismographs.

\subsection{Ice-Quakes over the Ice Sheet}

In addition to the events around the coastal area of Antarctica, there are different kinds of cryodynamic events within firn layers (i.e., the shallow part of the ice sheet, about $100 \mathrm{~m}$ depths from the surface) at the inland plateau of the ice 
sheet. The firn originating events have been called "snow-quakes" or "firn-quakes", which generate cracking "sounds" in the vicinity of their local areas. Seismic detection in terms of ice dynamics in the East Antarctic using temporary seismic arrays with combining global network data has been carried out after the big campaign of International Polar Year (IPY2007-2008). By checking the data from the "Antarctica's GAmburtsev Province (AGAP)"/the "GAmburtsev Mountain SEISmic experiment (GAMSEIS)", local seismic events were identified near Dome-F in the inland part of Dronning Maud Land [42].

Characteristic seismic events occurring inside the firn layer was investigated using the data from POLENET [43]. Sources of these firn-quakes have characteristics of dispersed surface-waves with propagation distances up to $1000 \mathrm{~km}$. These events are considered to be linking to form small fissures in the firn layers; moreover, the hypocentral location of these events might have a relation with a distribution of the crevasses over the ice-sheet surface layers [43]. Hypocenters of these events are supposed to be coincident with existing fissures, such as the location up-stream of Lambert Glacier, together with the inland plateau of the Transantarctic Mountains, respectively.

Recently, local ice-quakes were detected on the blue ice area of the East Antarctic ice sheet, near the Prince Elisabeth base in eastern Dronning Maud Land by one year's observation in 2012 [44]. They detected over 1500 ice-quakes nearby the bottom and found their occurring mechanism as thermally induced origins associated with contraction of ice caused by surface cooling. Detection of these cryoseismic events inside the ice sheet is an exciting topic on evaluating the influence of climate change toward the inland plateau of Antarctica, in terms of estimating the decreasing rate in the surface of the thick ice sheet.

Moreover, detection for the sub-glacial seismic events beneath the ice sheet and ice-streams could indirectly give new information on searching tremor events associated with the research topics on "sub-glacial hydrology". As another example, a significant number of ice-quakes were excited (i.e., "dynamic triggering") beneath the ice sheet of West Antarctic continent and West Antarctic Rift System (WARS) by using teleseismic surface waves triggered by large deep earthquakes occurred in South America [45] [46].

\section{Summary}

By this review paper, characteristics of seismic wavelets and involved seismicity in terms of cryosphere variations in bi-polar regions were demonstrated mainly studied by Japanese researchers. Hypocenters of frequent tectonic earthquakes, ice-quakes, as well as glacial earthquakes were found to locate around ice sheet margins, in particular, the calving front of outlet glaciers. However, the precise cause of the occurrence of these specific events has not been revealed entirely. Were they caused by a kind of seismic fault systems developing inside the vast "ice-mass", or the natural frictional sources of bedrocks and underlying ice sheet? 
Another candidate for triggering cryosiesmic events was supported by a kind of crustal uplift movement involving cryosphere deformation after deglaciation (i.e., the Glacial Isostatic Adjustment; GIA). Improvement of hypocentral calculation on local cryosphere events might be expected sufficiently, followed to clarify temporal-spatial distributions, basal conditions beneath the ice sheet, and generating source estimates in relation.

Cryoseismic events by various sources might occur significantly rare compared with tectonic earthquakes in the crust and upper mantle. Therefore, a statistic analysis with quantitative methods will be required to study their source intensity and frequency dependence in more detail by accumulating long-term data from monitoring networks.

For this concern, the "Cryoseismology", which combines cryosphere dynamics and associated seismic vibrations in the Earth's surface (crystallized rocks of the topmost crust cover majority areas), could be a new approach for investigating temporal-spacial variabilities of surface environment in the polar regions. More newly founds impacting on earth sciences and involved technical improvements in extreme environment condition will be expected in another one decade for the topics on this new branch of cryosphere-geosphere interactive science.

\section{Acknowledgements}

The author would like to express his sincere appreciation to many colleagues who dedicatedly supported to operate the seismic and infrasound deployments at both the polar regions, in particular, the members of the Japanese Antarctic Research Expeditions (JARE). This work was partially supported by JSPS KAKENHI Grand Number 26241010. Finally, the author would like to express thankfulness to reviewers for giving useful comments, as well as the editorial office for publishing this paper.

\section{Conflicts of Interest}

The author declares no conflicts of interest regarding the publication of this paper.

\section{References}

[1] Intergovernmental Panel on Climate Change (IPCC) (2013) Climate Change 2013: The Physical Science Basis, Contribution of Working Group I to the Fifth Assessment Report of the Intergovernmental Panel on Climate Change. Cambridge University Press, Cambridge, New York, 1535 p.

[2] Ekström, G., Nettles, M. and Tsai, V.C. (2006) Seasonality and Increasing Frequency of Greenland Glacial Earthquakes. Science, 311, 1756-1758. https://doi.org/10.1126/science.1122112

[3] MacAyeal, D., Okal, E.A., Aster, R.C. and Bassis, J.N. (2009) Seismic Observations of Glaciogenic Ocean Waves on Icebergs and Ice Shelves. Journal of Glaciology, 55, 193-206. https://doi.org/10.3189/002214309788608679 
[4] Podolskiy, E.A. and Walter, F. (2016) Cryoseismology. Reviews of Geophysics, 54, 708-758. https://doi.org/10.1002/2016RG000526

[5] Nettles, M. and Ekström, G. (2010) Glacial Earthquakes in Greenland and Antarctica. Annual Review of Earth and Planetary Sciences, 38, 467-491.

https://doi.org/10.1146/annurev-earth-040809-152414

[6] MacAyeal, D., Okal, E.A., Aster, R.C. and Bassis, J.N. (2008) Seismic and Hydroacoustic Tremor Generated by Colliding Icebergs. Journal of Geophysical Research, 113, F03011. https://doi.org/10.1029/2008JF001005

[7] Zoet, L.K., Anandakrishnan, S., Alley, R.B., Nyblade, A.A. and Wiens, D.A. (2012) Motion of an Antarctic Glacier by Repeating Tidally Modulated Earthquakes. Nature Geoscience, 5, 623-626. https://doi.org/10.1038/ngeo1555

[8] Winberry, J.P., Anandakrishnan, S., Wiens, D.A. and Alley, R.B. (2013) Nucleation and Seismic Tremor Associated with the Glacial Earthquakes of Whillans Ice Stream, Antarctica. Geophysical Research Letters, 40, 312-315.

https://doi.org/10.1002/grl.50130

[9] Hammer, C., Ohrnberger, M. and Schlindwein, V. (2015) Pattern of Cryospheric Seismic Events Observed at Ekstrom Ice Shelf, Antarctica. Geophysical Research Letters, 42, 3936-3943. https://doi.org/10.1002/2015GL064029

[10] Clinton, J.F., Nettles, M., Walter, F., Anderson, K., Dahl-Jensen, T., Giardini, D., Govoni, A., Hanka, W., Lasocki, S., Lee, W.S., McCormack, D., Mykkelveit, S., Stutzmann, E. and Tsuboi, S. (2014) Real-Time Geophysical Data Enhance Earth System Monitoring in Greenland. Eos, Transactions American Geophysical Union, 95, 13-24. https://doi.org/10.1002/2014EO020001

[11] Kanao, M., Maggi, A., Ishihara, Y., Yamamoto, M.-Y., Nawa, K., Yamada, A., Wilson, T., Himeno, T., Toyokuni, G., Tsuboi, S., Tono, Y. and Anderson, K. (2012) Interaction on Seismic Waves between Atmosphere-Ocean-Cryosphere and Geosphere in Polar Region. In: Kanao, M., Takenaka, H., Murai, Y., Matsushima, J. and Toyokuni, G., Eds., Seismic Waves-Research and Analysis, InTech, Rijeka, 1-20. https://doi.org/10.5772/23410

[12] Murayama, T., Kanao, M., Yamamoto, M.-Y., Ishihara, Y., Matshushima, T. and Kakinami, Y. (2015) Infrasound Array Observations in the Lützow-Holm Bay Region, East Antarctica. Polar Science, 9, 35-50. https://doi.org/10.1016/j.polar.2014.07.005

[13] Khan, S.A., Wahr, J., Bevis, M., Velicogna, I. and Kendrick, E. (2010) Spread of Ice Mass Loss into Northwest Greenland Observed by GRACE and GPS. Geophysical Research Letters, 37, L06501. https://doi.org/10.1029/2010GL042460

[14] Matsuo, K., Chao, B.F., Otsubo, T. and Heki, K. (2013) Accelerated Ice Mass Depletion Revealed by Low-Degree Gravity Field from Satellite Laser Ranging: Greenland, 1991-2011. Geophysical Research Letters, 40, 4662-4667. https://doi.org/10.1002/grl.50900

[15] Ekström, G., Nettles, M. and Abers, G.A. (2003) Glacial Earthquakes. Science, 302, 622-624. https://doi.org/10.1126/science.1088057

[16] Kanao, M., Suvorov, V.D., Toda, S. and Tsuboi, S. (2015) Seismicity, Structure and Tectonics in the Arctic Regions. Geoscience Frontiers, 6, 665-677. https://doi.org/10.1016/j.gsf.2014.11.002

[17] Toyokuni, G., Kanao, M., Tono, Y., Himeno, T., Tsuboi, S., Childs, D., Anderson, K. and Takenaka, H. (2014) Japanese Contribution to the Greenland Ice Sheet Monitoring Network (GLISN). Antarctic Record., 58, 1-18.

[18] Himeno, T., Kanao, M. and Ogata, Y. (2011) Statistical Analysis of Seismicity in a 
Wide Region around the $1998 \mathrm{Mw}$ 8.1 Balleny Islands Earthquake in the Antarctic Plate. Polar Science, 5, 421-431. https://doi.org/10.1016/j.polar.2011.08.002

[19] Veitch, S.A. and Nettles, M. (2012) Spatial and Temporal Variations in Greenland Glacial-Earthquake Activity, 1993-2010. Journal of Geophysical Research, 117, F04007. https://doi.org/10.1029/2012JF002412

[20] Roeoesli, C., Helmstetter, A., Walter, F. and Kissling, E. (2016) Meltwater Influences on Deep Stick-Slip Icequakes near the Base of the Greenland Ice Sheet. Journal of Geophysical Research: Earth Surface, 121, 223-240.

https://doi.org/10.1002/2015JF003601

[21] Toyokuni, G., Takenaka, H., Takagi, R., Kanao, M., Tsuboi, S., Tono, Y., Childs, D. and Zhao, D. (2017) Changes in Greenland Ice Bed Conditions Inferred from Seismology. Physics of the Earth and Planetary Interiors, 277, 81-98. https://doi.org/10.1016/j.pepi.2017.10.010

[22] Kalnay, E., Kanamitsu, M., Kistler, R., Collins, W., Deaven, D., Gandin, L., Iredell, M., Saha, S., White, G., Woollen, J., Zhu, Y., Chelliah, M., Ebisuzaki, W., Higgins, W., Janowiak, J., Mo, K.C., Ropelewski, C., Wang, J., Leetmaa, A., Reynolds, R., Jenne, R. and Joseph, D. (1996) The NCEP/NCAR 40-Year Reanalysis Project. Bulletin of the American Meteorological Society, 77, 437-471. https://doi.org/10.1175/1520-0477(1996)077<0437:TNYRP>2.0.CO;2

[23] Castellani, B.B., Shupe, M.D., Hudak, D.R. and Sheppard, B.E. (2015) The Annual Cycle of Snowfall at Summit, Greenland. Journal of Geophysical Research: Atmospheres, 120, 6654-6668. https://doi.org/10.1002/2015JD023072

[24] Rogozhina, I., Petrunin, A.G., Vaughan, A.P.M., Steinberger, B., Johnson, J.V., Kaban, M.K., Calov, R., Rickers, F., Thomas, M. and Koulakov, I. (2016) Melting at the Base of the Greenland Ice Sheet Explained by Iceland Hotspot History. Nature Geoscience, 9, 366-369. https://doi.org/10.1038/ngeo2689

[25] Wilson, T. and Bell, R. (2011) Earth Structure and Geodynamics at the Poles. In: Understanding Earth's Polar Challenges: International Polar Year 2007-2008, Art Design Printing Inc., Edmonton, 273-292.

[26] Kozlovskaya, E. (2013) Monitoring of Slow Seismic Events from Arctic Using the Data of the Polenet/Lapnet Broadband Temporary Array. IAHS-IASPO-IASPEI. IUGG Joint Assembly, Gothenburg, 22-26 July 2013.

[27] Kaminuma, K. (1994) Seismic Activity in and around the Antarctic Continent. Terra Antarctica, 1, 423-426.

[28] Iwata, T. and Kanao, M. (2015) The Quantitative Evaluation of the Annual Variation in the Teleseismic Detection Capability at Syowa Station, Antarctica. Polar Science, 9, 26-34. https://doi.org/10.1016/j.polar.2014.10.002

[29] Storchak, D.A., Kanao, M., Delahaye, E. and Harris, J. (2015) Long-Term Accumulation and Improvements in Seismic Event Data for the Polar Regions by the International Seismological Centre. Polar Science, 9, 5-16. https://doi.org/10.1016/j.polar.2014.08.002

[30] Kanao, M. (2017) Characteristics of Seismic Wave Propagation of Harmonic Tremors Observed at the Margin in the Lützow-Holm Bay, East Antarctica. In: Earthquakes-Tectonics, Hazard and Risk Mitigation, InTech, Rijeka, Chapter 4, 71-85.

[31] Kanao, M., Murayama, T., Yamamoto, M.-Y. and Ishihara, Y. (2017) Seismic Tremors and Their Relation to Cryosphere Dynamics in April 2015 around the LützowHolm Bay, East Antarctica. International Journal of Geosciences, 8, 1025-1047. https://doi.org/10.4236/ijg.2017.88058

[32] Powell, T.W. and Neuberg, J. (2003) Time Dependent Features in Tremor Spectra. 
Journal of Volcanology and Geothermal Research, 128, 177-185. https://doi.org/10.1016/S0377-0273(03)00253-1

[33] Talandier, J., Hyvernaud, O., Reymond, D. and Okal, E.A. (2006) Hydroacoustic Signals Generated by Parked and Drifted Icebergs in the Southern Indian and $\mathrm{Pa}$ cific Oceans. Geophysical Journal International, 165, 817-834. https://doi.org/10.1111/j.1365-246X.2006.02911.x

[34] Tanaka, Y., Hiramatsu, Y., Ishihara, Y. and Kanao, M. (2019) Characteristics of Non-Tectonic Tremors around the Lützow-Holm Bay, East Antarctica, during 2013-2015. Polar Science, 19, 77-85. https://doi.org/10.1016/j.polar.2018.11.010

[35] Eckstaller, A., Müller, C., Ceranna, L. and Hartmann, G. (2007) The Geophysics Observatory at Neumayer Stations (GvN and NM-II) Antarctica. Polarforschung, 76, 3-24.

[36] Lipovsky, B.P. and Dunham, E.M. (2016) Tremor during Ice-Stream Stick Slip. The Cryosphere, 10, 385-399. https://doi.org/10.5194/tc-10-385-2016

[37] Murayama, T., Kanao, M., Yamamoto, M.-Y., Ishihara, Y., Matsushima, T., Kakinami, Y., Okada, K., Miyamachi, H., Nakamoto, M., Takeuchi, Y. and Toda, S. (2017) Time-Space Variations of Infrasound Sources Related to Environmental Dynamics around the Lützow-Holm Bay, East Antarctica. Polar Science, 14, 39-48. https://doi.org/10.1016/j.polar.2017.10.001

[38] Moriwaki, K. and Yoshida, Y. (2002) Bathymetric Chart of Lützow-Holmbukta (Antarctica). NIPR Special Map Series, No. $4 \mathrm{~b}$.

[39] Nakamoto, M., Miyamachi, H., Matsushima, T., Kanao, M. and Yamamoto, M.-Y. (2016) Characteristics of Seismic Waveform Recorded by Seismic Array at East Ongul Island, Antarctica. JpGU2016, MTT05-P03, Makuhari, 22-26 May 2016.

[40] Nakamoto, M. and Kanao, M. (2018) Seismic Array Observations at East Ongul Island, Antarctica. Gekkan Chikyu, 468, 493-501. (In Japanese)

[41] Zigone, D., Voisin, C., Larose, E., Renard, F. and Campillo, M. (2011) Slip Acceleration Generates Seismic Tremor like Signals in Friction Experiments. Geophysical Research Letters, 38, L01315. https://doi.org/10.1029/2010GL045603

[42] Kanao, M. (2018) Seismic Detection in Inland Plateau of East Antarctica. In: Special Issue on "Polar Seismology_Advances and Impact", IntechOpen, London, 65-73.

[43] Lough, A.C., Wiens, D.A., Nyblade, A.A. and Anandakrishnan, S. (2017) A Previously Unreported Type of Seismic Source in the Firn Layer of the East Antarctic Ice Sheet. Journal of Geophysical Research: Earth Surface, 120, 2237-2252. https://doi.org/10.1002/2015JF003658

[44] Lombard, D., Gorodetskaya, I., Barruol, G. and Camelbeeck, T. (2019) Thermal Induced Icequakes Detected on Blue Ice Areas of the East Antarctic Ice Sheet. Annals of Glaciology, 60, 1-12. https://doi.org/10.1017/aog.2019.26

[45] Peng, Z., Walter, J.I., Aster, R.C., Nyblade, A.A., Wiens, D.A. and Anandakrishnan, S. (2014) Antarctic Icequakes Triggered by the 2010 Maule Earthquake in Chile. Nature Geoscience, 7, 677-681. https://doi.org/10.1038/ngeo2212

[46] Walter, J.I., Peng, Z., Tulaczyk, S.M., O’Neel, S. and Amundson, J.M. (2013) Triggering of Glacier Seismicity (Icequakes) by Distant Earthquakes. Seismological Research Letters, 84, 372. 